\title{
Kebijakan Jokowi Terhadap Pandemi Corona Virus Disease 19 (Covid-19): Dalam Persfektif Tindak Tutur
}

\author{
Sukardi $^{1}$ \\ ${ }^{1}$ UniversitasNahdlatulWathanMataram
}

*Sukardi:

UniversitasNahdlatulWathanMataram; Email: milasumba84@gmail.com

\begin{abstract}
Abstrak: Kajian tindak tutur ini menjadikan kebijakan Jokowi terhadap pandemi Covid-19 sebagai objek kajian. Tujuan kajian ini untuk mengetahui tindak tutur yang terdapat dalam kebijakan tersebut dan bagaimana perannya dalam membetuk suatu komunikasi yang efektif. Metode yang digunakan adalah metode kualitatif dengan mencatat, menyimak dan menelaah setiap ujaran atau kalimat yang diproduksi oleh penutur (Jokowi). Kajian ini menemukan tindak tutur ilokusi asertif, direktif, komisif, dan ekspresif. Tindak tutur tersebut terdiri dari dua bentuk yaitu tindak tutur langsung literal dan tindak tutur tidak langsung literal. Pada kajian ini juga ditemukan dalam ujaran-ujaran pada kebijakan tersebut fungsi komunikasi instrumental. Yaitu memberikan informasi kepada masyarakat, mengubah sikap dan keyakinan masyarakat, mengubah prilaku masyarakat, mendorong dan menggerakkan masyarakat untuk melakukan suatu tindakan.
\end{abstract}

Key word: Tindak tutur, Covid-19, komunikasi

Abstract: This speech act study takes Jokowi's policy on Covid-19 as object of study. This study's objective is to find out specch act that exists in the policy and how its role in creating an effective communication. The qualitative method is used by recording, listening and reading every utterances or sentences produced by Jokowi. This study found illocutions; assertives, directives, commisives and expressives. Those specch acts consist of direct literal specch act and non literal speech acts. In this research is also found in utturances on the policy intrumental function. Those are delivering information to people, changing people's attitude and belief, changing people's behaviour, stimulating and motivating the people to do an act.

Key word: Speech Acts, Covid-19, Communication.

\section{Pendahuluan}

Corona Virus Disease 19 yang dikenal luas dengan sebutan COVID-19 adalah wabah yang melanda lebih dari dua ratus negara di dunia. COVID-19 ini telah menjadi pandemi global yang telah menarik perhatian para pemimpin negaranegara di dunia untuk mengeluarkan kebijakan publik (public policy). Salah satunya adalah Presiden Indonesia yaitu Bapak Joko Widodo. Pada tanggal 15 Maret 2020 Bapak Jokowi telah mengeluarkan kebijakan sebagai bentuk tanggapan terhadap ancaman COVID-19 yang semakin serius di Negara Indonesia. Kebijakan yang dikeluarkan diharapkan mampu memberikan pengaruh positif di masyarakat yang terus semakin resah dan panik dengan ancaman pandemi tersebut. Kebijakan merupakan salah satu bentuk komunikasi seorang pemimpin negara untuk mengatur masyarakat atau rakyatnya.

Keberhasilan suatu kebijakan dapat dilihat dari bahasa yang digunakan. Karena bahasa merupakan satu-satunya alat untuk menyampaikan kebijakan baik dalam bentuk lisan ataupun tulisan. Keberhasilan kebijakan dapat ditentukan dari pilihan kata, frasa dan bentuk kalimat yang digunakan. Pilihan kata, frasa dan bentuk kalimat 
memberikan makna atau informasi yang bisa dipahami dengan mudah atau sebaliknya oleh masyarakat. Apakah kebijakan itu berupa anjuran, perintah atau larangan. Jika pilihan kata, frasa dan bentuk kalimat itu tepat maka esensi dari kebjikan tersebut mudah dipahami oleh masyarakat sehingga kebijakan itu bisa ditaati atau dilaksanakan dengan baik.

Menurut Yule (1996) sebagaimana yang dikemukakan dalam Sumarti (2015) bahwa fungsi komunikasi secara umum terdiri atas pernyataan, pertanyaan, dan perintah atau permohonan. Artinya sebuah komunikasi tidak terlepas dari ketiga hal tersebut. Menurut pendapat tersebut ada beberapa jenis kalimat yang dapat digunakan dalam membuat suatu kebijakan sebagai bentuk komunikasi di antaranya kalimat deklaratif, kalimat imperatif dan kalimat interogatif. Kalimat deklaratif adalah kalimat yang menunjukkan berita, informasi dan pernyataan. Kalimat interogatif adalah kalimat yang menunjukkan pertanyaan. Kalimat imperatif adalah kalimat yang struktur kalimatnya menunjukkan perintah, himbauan, larangan dan ajakan. Oleh karena itu bahasa memiliki peran penting dalam keberhasilan sebuah kebijakan.

Menurut William I. Golden dalam Mulyana (2010:5-27) fungsi komunikasi itu ada empat. Pertama, fungsi komunikasi sebagai komunikasi sosial. Fungsi ini mengisyaratkan bahwa komunikasi itu penting untuk membangun konsep diri, aktualisasi diri, untuk kelangsungan hidup, memperoleh kebahagiaan, terdindar dari tekanan dan ketegangan. Kedua, fungsi komunikasi sebagai komunikasi ekspresif. Komunikasi ekspresif berfungsi sebagai alat untuk menyampaikan perasaan (emosi) terutama melalui pesan-pesan nonverbal dengan tujuan untuk mempengaruhi orang lain. Ketiga, fungsi komunikasi ritual. Fungsi komunikasi ritual ini adalah memungkinkan para pesertanya berbagi komitmen emosional dan menjadi perekat perasaan senasib sepenanggungan yang menyertainya. Biasanya terjadi dalam acaraacara ritual. Keempat, fungsi komunikasi instrumental. Komunikasi instrumental memiliki tujuan yaitu, menginformasikan, mengajar, mendorong, mengubah sikap dan keyakinan, mengubah perilaku atau menggerakkan tindakan, dan menghibur. Melalui komunikasi pemerintah dapat bekerja sama dengan masyarakat untuk mencapai tujuan bersama dan masyarakat akan tahu panduan untuk memahami dan menafsirkan situasi yang sedang dihadapi.

Berbicara mengenai penggunaan bahasa dalam sebuah kebijakan dapat dilihat dari sudut pandang pragmatik pada perspektif tindak tutur.

Tindak tutur merupakan analisis Pragmatik, yaitu cabang ilmu bahasa yang mengkaji bahasa dari aspek penggunaannya. Leech (1983:5-6) mengemukakan bahwa pragmatik mengkaji maksud ujaran (yaitu untuk apa ujaran itu dilakukan); mengkaji apa yang seseorang maksudkan dengan suatu tindak tutur; dan mengaitkan makna dengan siapa berbicara, kepada siapa, di mana, bilamana, bagaimana.

Searle (1969) dalam Mohammad Siddiq (2019) mengatakan "the speech act is the basic unit of communication, taken together with the principle of expressibility, suggests that there are a series of analytic connections between the notion of speech acts, what the speaker means, what the sentence (or other linguistic element) uttered means, what the speaker intends, what the hearer understands, and what the rules governing the linguistic elements are (Searle, 1969: 22-24). Menurutnya tindak tutur itu merupakan dasar sebuah komunikasi yang dipadukan dengan prinsip bagaimana gagasan dalam pikiran diungkapkan dengan bahasa melalui serangkaian hubungan analitis antara tindak tutur dengan apa yang hendak disampaikan penutur, perangkat linguistik yang diucapkan, apa yang dipahami pendengar dan aturan yang mengatur unsur-unsur linguistik tersebut.

Bahasa yang digunakan dalam kebijakan publik baik dalam bentuk lisan ataupun tulisan jika dilihat dari perspektif tindak tutur sama seperti sebuah tindakan. Sebagaimana yang dikatakan oleh salah satu pencetus teori Tindak Tutur, John Austin (1962), "by saying something we do something". Menurut teori tersebut setiap kali pembicara membuat ujaran atau mengucapkan suatu kalimat, ia sedang berupaya melakukan sesuatu dengan ujuran atau kalimat itu.

Ada dua jenis makna yang terdapat pada ujaran atau kalimat dalam kebijakan publik menurut teori tersebut yaitu makna proposisional atau makna lokusioner (locutionary meaning) dan makna ilokusioner (illocutionary meaning). Makna lokusioner adalah makna harfiah dari ujuran atau kalimat yang terucap. Untuk memahaminya harus menggunakan pengetahuan gramatikal dan kosa kata. Makna ilokusioner adalah efek yang 
diharapkan muncul dari pernyataan tersebut kepada pendengarnya.

Searle (dalam Leech 1993) mengklasifikasikan tindak tutur menjadi lima sebagaimana yang dikutip oleh Farrah Fitriah dan Siti Sarah (2017). Pertama, komisif (commisive) yaitu tindak tutur yang menyatakan bahwa pembicara akan melakukan sesuatu di masa yang akan datang, seperti berjanji atau mengancam. Contoh, Dia akan membunuhmu jika membongkar rahasianya. Kedua, deklaratif (declarative) yaitu tindak tutur yang dapat mengubah keadaan. Contoh, hasil pemeriksaan serologi menyatakan anda positif terinfeksi COVID-19. Ketiga, direktif (directive) yaitu tindak tutur yang berfungsi meminta pendengar melakukan sesuatu seperti permintaan, perintah, dan larangan. Contoh, jangan menginjak tanaman ini. Keempat, ekspresif (expressive) yaitu tindak tutur yang digunakan oleh pembicara untuk mengungkapkan perasaan dan sikap terhadap sesuatu. Contohnya, saya suka dengan bunga ini. Kelima, asertif (assertive) yaitu tindak tutur yang mengikat penutur dengan kebenaran proposisi yang diungkapkan, misalnya menyatakan, mengusulkan, mengeluh, mengemukakan pendapat, dan melaporkan. Contoh, Pendakian ke Gunung Rinjani akan ditutup besok.

Dari keterangan-keterangan itu dapat ditarik sebuah kesimpulan bahwa tindak tutur (speech act) merupakan kajian analisis fungsi bahasa (language function) yaitu apa tujuan bahasa digunakan, seperti meminta, menyatakan, menghukum, menasehati. Fungsi-fungsi itu tidak saja ditentukan dari bentuk struktur gramatikalnya, tetapi juga ditentukan dari konteks bahasa tersebut digunakan.

Artikel ini mengkaji jenis tindak tutur yang digunakan dalam kebijakan yang dibuat oleh Presiden Joko Widodo dalam menghadapi ancaman wabah COVID-19 berdasarkan teori tindak tutur yang dijelaskan oleh Searle. Selain itu artikel ini juga mengkaji fungsi komunikasi yang dibangunnya melalui jenis tindak tutur tersebut.

\section{Metode}

Penelitian ini menggunakan pendekatan kualitatif. Data dalam penelitian ini berupa kalimat atau ujaran Bapak Joko Widodo dalam membuat kebijakan publik sebagai bentuk aksi tanggap terhadap wabah COVID-19 yang diperoleh dari Youtube dan media online Indopolitika https://indopolitika.com. Teknik pengumpulan data dilakukan dengan teknik simak dan baca. Teknik simak digunakan untuk mengetahui intonasi, mimik dan gesture Bapak Jokowi dalam menyampaikan kebijakan. Teknik baca digunakan untuk mendapatkan informasi bentuk struktur kalimat yang tepat dari ujaran yang disampaikan. Setelah data terkumpul kemudian dilakukan pengklasifikaan data berdasarkan teori Tindak Tutur yang dikemukakan oleh John Searle. Selanjutnya, data yang telah diklasifikan kemudian dianalisis. Penganalisisan data dilakukan dengan memperhatikan aspek tekstual adan kontekstual. Dalam menganalisis fungsi komunikasi yang terdapat pada data tidak hanya fokus pada bentuk kalimat atau ujaran, tetapi juga pada konteks yang mengikutinya.

\section{Hasil dan Pembahasan}

\section{Hasil}

Beberapa jenis tindak tutur yang ditmukan dalam kajian ini di antaranya; asertif, direktif, komisif dan ekspresif. Dari beberapa jenis tindak tutur tersebut ada yang berbentuk tindak tutur langsung literal dan tindak tutur tidak langsung literal. Selainitu, dalam kajian ini juga ditemukan bahwa semua ujaran dalam kebijakan itu mempunyai satu bentuk fungsi komunikasi yaitu fungsi komunikasi instrumental.

\section{Pembahasan}

Kebijakan yang dibuat oleh Bapak Jokowi pada tanggal 15 Maret 2020 merupakan bentuk komunikasi instrumental kepada jajaran pemerintahan yang dimilikinya dan juga kepada seluruh masyarakat Indonesia dalam rangka tanggap darurat terhadap pandemi covid-19. Hal ini menjadikon teks keluarnya kebijakan tersebut.

Keberhasilan kebijakan tersebut tergantung pada kepiawaian penutur (Bapak Joko Widodo) menggunakan bahasa dalam membuat suatu kebijakan. Kebijakan yang baik adalah kebijakan yang mudah dipahami dan kebijakan yang kuat adalah kebijakan yang memiliki fungsi komusikasi yang sangat kuat. Kekuatan suatu komunikasi dapat kita lihat dari tindak tuturilokusi yang terdapat dalam kalimat atau ujaran yang digunakan dalam membuat suatu kebijakan. Muhammad Siddiq (2019) mengatakan bahwa tindak tuturilokusi adalah tindak tutur yang mengandung maksud dan fungsi komunikasi atau daya tuturan. Artinya, tindak tuturilokusi merupakan gagasan yang 
terkandung dalam bahasa yang digunakan dalam membentuk kebijakan baik berbentuk kalimat atau ujaran. Penelitian ini berusaha mengungkap tindak tuturilokusi yang terdapat dalam kebijakan Jokowi tersebut untuk mengetahui gagasan atau maksud yang disampaikan.

Jokowi dalam memulai setiap kebijakan selalu diawali oleh ungkapan salam dan sapaan.

Bismillahhirrohmannirohim

Assalamualaikum War Wab

Selamat siang,

Salam sejahtera bagi kita semuanya,

Om Swastiastu,

Namo Buddhaya,

Salam Kebajikan,

Bapak Ibu dan Saudara-saudara sebangsa dan

setanah air,

Dilihat dari salam yang diucapkan, Jokowi mengungkapkan salam yang berasal dari beberapa agama yang ada di Indonesia. Tindak tutur ini merupakan tidak tutur ekspresif. Fungsi komunikasi yang disampaikan dalam tindak tutur tersebut adalah Jokowi ingin mengungkapkan persaan dan sikapnya untuk menyapa seluruh masyarakat Indonesia yang menganut lebih dari satu agama.

Setelahmenyapadengansalam,

Jokowilangsungmeneruskanujarannya.

Sejak kita mengumumkan adanya kasus Covid19 di awal bulan ini, saya telah memerintahkan kepada Menteri Kesehatan dan kementerian terkait untuk meningkatkan langkah-langkah ekstra dalam menangani pandemik global Covid19 ini.

Ujaran tersebut sekilas terlihat seperti sebuah kalimat berita karena menggunakan kalimat deklaratif. Jika ditelaah lebih dalam ujaran tersebut menggunakan dua bentuk dan kalimat dengan subjek yang berbeda. Kedua bentuk kalimat tersebut juga memiliki jenis tindak tutur yang berbeda. Pertama, Tindak tutur asertif. Tindak tutur ini terdapat pada ujaran "Sejak kita mengumumkan adanya kasus Covid19 di awal bulan ini". Ujaran ini adalah kalimat deklaratif dengan subjek 'kita', yang memberikan pernyataan berupa informasi suatu kasus. Kedua, tindak tutur direktif. Tindak tutur ini terdapat pada ujaran "saya telah memerintahkan kepada Menteri Kesehatan dan kementerian terkait untuk meningkatkan langkahlangkah ekstra dalam menangani pandemik global Covid19 ini." Ujaran itu merupakan tidak tutur direktif yang dikemas dalam bentuk kalimat deklaratif beraspek perfektif dan berkala lampau.
Ujaran tersebut bermakna imperatif karena menggunakan subjek 'saya' dan diikuti verba 'memerintahkan' yang menunjukkan penutur memberikan perintah kepada mitra tuturnya untuk melakukan suatu perbuatan. Menurut Ahmad Saifudin (2019) tindak tutur direktif seperti ini disebut sebagai tindak tutur direktif tidak langsung karena tidak adanya hubungan antara bentuk kalimat dengan tindak tuturnya. Tidak tutur direktif tidak langsung mempunyai daya tindak tutur yang kurang kuat.

Kita melihat, beberapa negara yang mengalami penyebaran lebih awal dari kita, ada yang melakukan lock-down dengan segala konsekuensi yang menyertainya. Tetapi ada juga negara yang tidak melakukan lock-down, namun melakukan langkah dan kebijakan yang ketat untuk menghambat penyebaran Covid19.

Ujaraninimerupakanujarantindaktuturasertif.

Bentuk kalimat yang digunakan adalah deklaratif yang berfungsi untuk menyampaikan informasi, pernyataan atau berita. Fungsi komunikasi yang dibangun dalam ujaran tersebut adalah memberikan informasi kepada masyarakat bahwa perbedaan cara menangani penyebaran wabah COVID-19 yang dilakukan oleh negara-negara yang telah lebih awal mengalaminya. Ada negara yang melakukan lock down ada juga yang tidak melakukannya.

Pemerintah terus berkomunikasi dengan WHO dan mempergunakan Protokol Kesehatan WHO, serta berkonsultasi dengan para ahli kesehatan masyarakat dalam menangani penyebaran Covid19 ini.

Ujaran ini termasuk tindak tutur komisif. Tindak tutur komisif pada ujaran ini juga menggunakan kalimat deklaratif. Dalam struktur kalimat itu penutur menggunakan kata 'terus' yang mengindikasikan terjadinya sebuah tindakan secara kontinyu (terus-menerus). Artinya, apa yang sedang dilakukan oleh penutur akan terus dilakukan di masa yang akan datang. Akan tetapi, pada data ini tidak ada verba lokusi yang sesuai dengan tindak tutur dalam ujaran itu. Sehingga tindak tutur ini termasuk tindak tutur komisif tidak langsung.

Pemerintah telah membentuk Gugus Tugas Percepatan Penanganan Covid19, yang diketuai oleh Kepala Badan Nasional Penanggulangan Bencana, Letjen TNI Doni Monardo. Gugus tugas ini telah bekerja secara efektif dengan mensinergikan kekuatan nasional, baik di pusat maupun di daerah, melibatkan ASN, TNI dan 
POLRI, serta melibatkan dukungan dari swasta, lembaga sosial dan perguruan tinggi.

Ujaran ini adalah tindak tutur asertif. Bentuk kalimat yang digunakan adalah kalimat deklaratif. Dalam ujaran tersebut Jokowi menegaskan bahwa pemerintahan yang dipimpinnya telah membentuk Gugus tugas percepatan penanganan COVID-19 yang melibatkan TNI, ASN, dan POLRI serta melibatkan swasta, LSM dan perguruan tinggi

Sebagai negara besar dan negara kepulauan, tingkat penyebaran Covid19 ini derajadnya bervariasi antar daerah. Oleh karena itu, saya minta kepada seluruh Gubernur dan Bupati serta Walikota:

- Untuk terus memonitor kondisi daerah dan terus berkonsultasi dengan pakar medis dalam menelaah situasi;

- Kemudian, terus berkonsultansi dengan Badan Nasional Penanggulangan Bencana untuk menentukan status daerahnya siaga darurat ataukah tanggap darurat bencana non-alam.

Dalam ujaran-ujaran tersebut terdapat tindak tutur asertif dan tindak tutur direktif. Tindak tutur asertif ini mengawali ujaran-ujaran tersebut. Dalam tindak tutur asertif ini Jokowi menyampaikan informasi mengenai kondisi Negara Indonesia dan tingkat penyebaran Covid-19. Kemudian dilanjutkan dengan ujaran-ujaran imperatif yang merupakan tindak tutur direktif.

Konstruksi kalimat ujaran imperatif tersebut menggunakan pronomina orang pertama (saya) dan verba imperatif (meminta). Hal ini menunjukkan adanya kesesuaian antara bentuk tindak tutur dengan verba yang digunakan. Tindak tutur langsung (Yule, 1990; Wijana, 1996) adalah tindak tutur yang struktur tuturan dan fungsi komunikasinya sama. Selain itu, komunikasi yang dibangun dalam ujuran imperatif itu adalah Jokowi menunjukkan ketegasannya dalam memberikan suatu instruksi dengan menghadirkan pronomina 'saya' yang diikuti langsung oleh verba imperatif 'minta'. Dalam hal ini Jokowi memerintahkan kepada Gubernur, Bupati dan Walikota untuk melakukan monitoring kondisi wilayah dan konsultasi dengan Badan Nasional Penanggulangan Bencana (BNPB) untuk menetapkan status daerah siaga darurat atau tanggap darurat bencana alam.

Berdasarkan status kedaruratan daerah tersebut, jajaran Pemerintah Daerah dibantu jajaran TNI dan POLRI serta dukungan dari pemerintah pusat untuk terus melakukan langkah- langkah yang efektif dan efisien dalam menangani penyebaran dan dampak Covid19.

- Membuat kebijakan tentang proses belajar dari rumah bagi pelajar dan mahasiswa.

-Membuat kebijakan tentang sebagian ASN bisa bekerja di rumah dengan menggunakan interaksi on-line, dengan tetap mengutamakan pelayanan yang prima kepada masyarakat.

- Menunda kegiatan-kegiatan yang melibatkan peserta banyak orang.

- Meningkatkan pelayanan penge-test-an infeksi Covid19 dan pengobatan secara maksimal, dengan memanfaatkan kemampuan Rumah Sakit Daerah, dan bekerja sama dengan Rumah Sakit swasta, serta lembaga riset dan pendidikan tinggi, yang direkomendasikan oleh Kementerian Kesehatan.

Dalam ujaran tersebut seolah terlihat bukan sebuah ujaran imperatif. Di dalamnya tidak terdapat kata kerja imperatif seperti memerintahkan, menyuruh, menugaskan, dan tidak adanya pronomina saya. Akan tetapi, ujuran tersebut bermakna imperatif dengan adanya klausa ......Pemerintah Daerah dibantu jajaran TNI dan POLRI serta dukungan dari pemerintah pusat untuk terus melakukan langkah-langkah...... sehingga ujaran tersebut merupakan tindak tutur direktif.

Perintah yang disampaikan Jokowi dalam ujaran itu merupakan bentuk tindak tutur direktif tidak langsung literal. Menurut Wijana (1989:33) tindak tutur tidak langsung literal adalah tindak tutur yang diungkapkan dengan modus tuturan dan makna tidak sesuai dengan maksud pengutaraannya, tetapi kata-kata yang menyusunya sesuai dengan apa yang dimaksudkan penutur. Dalam tindak tutur ini penutur bermaksud memberikan perintah disampaikan dengan kalimat berita atau kalimat tanya.

Saya sudah perintahkan untuk memberikan dukungan anggaran yang memadai untuk digunakan secara efektif dan efisien.

Ujaran tersebut adalah kalimat deklaratif. Ujaran tersebut bisa bermakna informasi atau imperatif. Jika melihat ujaran setelah ujaran tersebut maka ujaran tersebut bermakna imperatif. Oleh karena itu ujaran tersebut adalah tindak tutur direktif. Kalimat ujaran tersebut beraspek perfektif dan berkala lampau. Ujaran tersebut bermakna imperatif karena menggunakan verba 'perintahkan' dan menghadirkan pronomina 'saya' yang menunjukkan penutur memberikan perintah dengan 
tegas kepada mitra tuturnya untuk melakukan suatu perbuatan. Tindak tutur ini termasuk tindak tutur direktif langsung literal karena makna yang terkandung dalam ujaran tersebut sama dengan modus tuturannya.

- Pertama, merujuk pada UU No 24 Tahun 2007 tentang Penanggulangan Bencana, yang memungkinkan pemerintah dan pemerintah daerah untuk memprioritaskan dan menggunakan anggaran secara cepat.

- Selain itu, Menteri Keuangan juga sudah mengeluarkan peraturan dan pedoman untuk penyediaan anggaran yang diperlukan oleh seluruh Kementerian Lembaga dan Pemerintah Daerah dan Gugus Tugas Percepatan Penanganan Covid19.

- Peraturan ini memberikan landasan hukum agar pihak yang relevan dapat menggunakan anggarannya dan mengajukan kebutuhan anggaran tambahan untuk menangani tantangan penyebaran Covid19.

Ujaran-ujaran tersebut berupa kalimat deklaratif yang menunjukkan keyakinan dan pernyataan Jokowi. Ujaran itu menjadi dasar dalam memberikan perintah pada ujaran sebelumnya. Ujaran-ujaran itu adalah tidak tutur asertif. Yule dalam Sitti Hajija (2017) mengatakan bahwa tindak tutur asertif adalah tidak tutur yang menyatakan apa yang diyakini oleh penutur apakah kasus atau bukan seperti mendeskripsikan sebuah keadaan atau peristiwa, mengemukakan pendapat dan melaporkan.

Dampak pandemik Covid19 ini telah memperlambat ekonomi dunia secara masif dan signifikan, termasuk terhadap perekonomian Indonesia. Untuk itu, pemerintah telah dan terus melakukan langkah-langkah cepat untuk mengantisipasi beberapa dampak ini.

-Pemerintah memastikan ketersediaan bahan kebutuhan pokok yang cukup dan memadai untuk memenuhi kebutuhan masyarakat.

Ujaran ini menunjukkan sebuah sebab akibat. Sebab dalam ujaran ini diungkapkan dalam bentuk tindak tutur asertif sedangkan akibat diungkapkan dalam bentuk tindak tutur komisif. Penutur dengan ujaran tindak tutur asertif tersebut menyatakan dampak covid-19 berupa perlambatan ekonomi global. Penutur dengan ujaran tindak tutur komisif memberikan sebuah jaminan kepada mitra tutur pada waktu yang akan datang. Menurut Mursia Ekawati (2017) tindak tutur komisif adalah tindak tutur yang terkait dengan apa yang akan dilakukan oleh penutur di masa yang akan datang, seperti berjanji, berniat, memberi jaminan.

Tindak tutur komisif dalam ujaran ini menggunakan kalimat deklaratif. Fungsi kalimat deklaratif pada tindak tutur ini adalah untuk memberikan informasi mengenai apa yang akan dilakukan oleh penutur kepada mitra tuturnya. Di dalam ujaran tersebut terdapat kata kerja 'memastikan' yang sesuai dengan tindak tutur komisif. Kata 'memastikan' memiliki makna yaitu memberikan pemahaman kepada mitra tutur bahwa penutur akan melakukan sesuatu untuk menjamin ketersediaan bahan kebutuhan pokok yang cukup dan memadai untuk memenuhi kebutuhan mitra tutur. Verba ilokusi 'memastikan' pada ujaran tersebut sesuai dengan jenis tindak tuturnya sehingga tindak tutur pada data ini termasuk kategori tindak tutur komisif langsung literal yang memiliki makna penegasan pemerintah (penutur).

-Pemerintah juga telah memberikan insentif kebijakan ekonomi, sebagaimana telah diumumkan oleh Menko Perekomian dan jajaran menteri perekonomian, untuk menjaga agar kegiatan dunia usaha tetap berjalan seperti biasa.

Tindak tutur pada ujaran ini adalah tindak tutur asertif. Tindak tutur asertif ini berbentuk kalimat deklaratif berupa pernyataan yang menguatkan tidak tutur komisif sebelumnya. Pada tindak tutur ini penutur menegaskan bahwa pemerintah telah memberikan insentif kebijakan ekonomi agar kegiatan dunia usaha tetap bisa berjalan.

-Saya juga minta kepada Kepala Daerah untuk mendukung kebijakan ini dan melakukan kebijakan yang memadai di daerah.

- Perintah yang disampaikan Jokowi dalam ujaran tersebut merupakan bentuk tindak tutur direktif langsung literal. Menurut Yule dalam Wijana (1996) tindak tutur direktif langsung adalah tindak tutur yang struktur tuturan dan fungsi komunikasinya sama. Hal itu ditunjukkan dengan bentuk kalimat perintah yang digunakan untuk memerintah. Penutur bermaksud memerintah dan perintahnya disampaikan dalam kalimat perintah. Tindak tutur ujaran itu memiliki makna perintah yang sangat kuat dan tegas. Selain itu kehadiran pronominal 'saya' dan kehadiran verba imperatif ' minta' yang berada setelahnya juga mempertegas maksud sebuah tuturan perintah tersebut.

Saya dan seluruh jajaran kabinet terus bekerja keras untuk menyiapkan dan menjaga Indonesia 
dari penyebaran Covid19 dan meminimalkan implikasinya terhadap perekonomian Indonesia.

Ujaran ini berbentuk kalimat deklaratif. Dalam struktur kalimatnya terdapat kata 'terus' yang bermakna 'kontinuitas'. Artinya ada sebuah tindakan yang dilakukan penutur yang telah berlangsung sebelum penutur menyampaikan ujaran tersebut dan perbuatan tersebut akan tetap eksis pada masa yang akan datang. Ujaran tersebut dikategorikan tindak tutur komisif komisif karena di dalam diri penutur terdapat niat untuk terus melakukan tindakan tersebut di masa yang akan datang. Menurut Mursia Ekawati (2017) tindak tutur komisif adalah tindak tutur yang terkait dengan apa yang akan dilakukan oleh penutur di masa yang akan datang, seperti berjanji, berniat, memberi jaminan.

- Sebagaimana kemarin telah disampaikan, bahwa salah satu menteri kami terdeteksi positif terinfeksi Covid19.

- Langkah-langkah antisipatif telah dilakukan, dan saya yakinkan bahwa para menteri tetap bekerja penuh seperti biasa.

- Bahkan, hari-hari ini para menteri bekerja lebih keras, walaupun sebagian dilakukan dengan cara on-line, untuk mengatasi isu kesehatan dan mengatasi dampak perekonomian akibat Covid19 ini.

Ujaran-ujaran tersebut berbentuk kalimat deklaratif. Semua ujaran tersebut termasuk tindak tutur asertif. Di dalam tindak tutur tersebut penutur menyampaikan berita mengenai salah satu menterinya terpapar covid-19, langkah-langkah antisipatif pencegahan covid-19, dan usaha yang dilakukan para menteri dalam mengatasi dampak kesehatan dan dampak ekonomi yang ditimbulkannya.

Terakhir, kepada seluruh rakyat Indonesia, saya minta untuk tetap tenang, tidak panik, dan tetap produktif dengan meningkatkan kewaspadaan agar penyebaran Covid19 ini bisa kita hambat dan kita stop. Dengan kondisi ini, saatnya kita kerja dari rumah, belajar dari rumah, ibadah di rumah. Inilah saatnya bekerja bersama-sama, saling tolong menolong ,dan bersatu padu, gotong royong, kita ingin ini menjadi sebuah gerakan masyarakat agar asalah covid 19 ini bisa tertangani dengan maksimal.

Jokowi mengakhiri kebijakannya dengan perintah sekaligus ajakan untuk menghambat penyebaran virus covid-19. Dalam ujaran tersebut terdapat kalimat dengan subjek 'saya' yang diikuti verba imperatif 'meminta' menunjukkan bahwa kalimat itu adalah kalimat perintah. Pronomina 'saya' yang dikuti verba imperatif tersebut mengangdung makna tegas. Artinya, dalam setiap memberikan perintah Jokowi selalu menyampaikannya dengan tegas. Sebaliknya, dalam perintah yang berupa ajakan Jokowi menggunakan pronomina ' kita' sebagai subjek kalimatnya. Penggunaan pronomina 'kita' mengandung makna bahwa penutur mengajak mitra tutur dan dirinya sendiri untuk melakukan hal yang sama seperti yang diujarkannya. Hal ini menunjukkan bahwa Jokowi tetap santun kepada mitra tuturnya. Oleh karena itu, ujaran tersebut merupakan tindak tutur direktif langsung literal.

Saya kira ini yang bisa saya sampaikan. Terima kasih.

Wassalamualaikum War Wab

Om Santi, Santi, Santi Om

Ujaran tersebut merupakan tindak tutur ekspresif. Menurut Eka Nur Insani dan Atiqa Sabardila (2016) bahwa tindak tutur ekspresif adalah tindak tutur yang digunakan oleh pembicara untuk mengungkapkan perasaan psikologis dan sikap penutur terhadap sesuatu. Di antara yang termasuk tindak tutur ekpresif adalah mengucapkan rasa terima kasih, meminta maaf, mengucapkan belasungkawa, dan mengucapkan salam. Pada kebijakan jokowi tangga1 15 Maret 2020 hanya ada dua ujaran yang termasuk kategori tindak tutur ekspresif. Tindak tutur ini terdapat di awal dan di akhir kebijakan itu.

Bentuk kalimat dan tindak tutur pada ujaran tersebut mempunyai kesesuaian. Dengan demikian, tindak tutur ekpresif ini adalah tidak tutur ekspresif langsung literal. Fungsi komunikatif yang ingin disampaikan dalam tindak tutur ini adalah penutur ingin mengungkapkan perasaan dan sikapnya kepada mitra tuturnya dengan ujaran sapaan sesuai dengan agama yang dianutnya.

Semua ujaran tersebut dapat disimpulkan mempunyai satu bentuk fungsi komunikasi yaitu komunikasi instrumental. Fungsi komunikansi instrumental yang terdapat dalam ujaran-ujaran tersebut adalah menginformasikan, mendorong, mengubah sikap dan keyakinan, mengubah prilaku dan menggerakkan tindakan.

\section{Kesimpulan}


Kebijakan Bapak Joko Widodo pada tanggal 15 Maret 2020 mengandung ujaran-ujaran yang dari sudut pandang ilmu pragmatik memiliki jenis tindak tutur yang berbeda. Tindak tutur dalam kebijakan itu terdiri dari ekspresif, komisif, asertif dan direktif. Dari keempat tindak tutur tersebut ada yang berbentuk tindak tutur langsung literal dan tindak tutur tidak langsung literal. Selain itu, ujaran-ujaran tersebut mengandung fungsi komunikasi instrumental yaitu memberikan informasi kepada masyarakat, mengubah sikap dan keyakinan masyarakat, mengubah prilaku masyarakat dan mendorong serta menggerakkan masyarakat untuk melakukan suatu tindakan.

\section{Daftar Pustaka}

Austin, J.L. (1962). How to do things with word. London: Oxford University Press.

Ekawati, M, (2017).Kesantunan Semu pada Tindak Tutur Ekspresif Marah dalam Bahasa Indonesia, Volume 1 Nomor 1, Juni 2017, hlm. 1-22.

Fitirah, Farrah \& Sarah F, Siti. (2017).

AnalisiTindakTuturdalam Novel Marwah di Ujung Bara Karya R.H. Fitriadi, Volume 5 Nomer 1, Januari 2017, hlm.51-62.

Insani, Eka N \&Sarbadila, A. (2016).TindakTuturPerlokusidalamPembelajara nbahasa Indonesia Kelas XI SMK Negeri 1 SawitBoyolali, Volume 17 Nomor 2, hlm.176184.

Leech, G. 1993. Prinsip-Prinsip Pragmatik. Jakarta: Penerbit Universitas Indonesia (UIPRESS).

Mulyana, Dedi. 2010. Ilmu Komunikasi Suatu Pengantar. Bandung: PT Remaja Rosdakarya.

Saifudin, Ahmad. 2019. Teori Tindak Tutur dalam Studi Linguistik Pragmatik, Volume 15 No 1, Maret 2019, hlm. 1-16.

Searle, JR. 1969. Speech Act: An Essay in The Philosophy of Language. United Kindong: Cambridge University.
Siddiq, Muhammad. 2019. Tindak Tutur dan Pemerolehan Pragmatik pada Anak Usia Dini, Volume 2 No. 2, hlm 268-290.

Wijayana, I D. 1996. Dasar-dasar Pragmatik. Yogyakarta: Andi Offset.

Yuliana, Rina, dkk. (2013) Daya Pragmatik Tindak Tutur Guru dalam Pembelajaran Bahasa Indonesia pada Siswa Sekolah Menengah Pertama, Volume 2 Nomor 1, April 2013, hlm. 1-14. 